DOI No: http://dx.doi.org/10.29228/Joh42814

Makale Türü: Araştırma makalesi

Geliş Tarihi: 09.04.2020

Kabul Tarihi: 28.05.2020

On-line Yayın: 25.06.2020
ArticleType: Research article

Submitted: 09.04.2020

Accepted: 28.05 .2020

Published Online: 25.06.2020

Atıf Bilgisi / Reference Information

Kizilkoca, M., Özcan, E. \& Albayrak, V. (2020). An Investigation of Effect of Problem-Solving Skill on Job Satisfaction of Provincial Football Referees in Eastern Anatolian Region. Journal of History School, 46, 1873-1889.

\title{
AN INVESTIGATION OF EFFECT OF PROBLEM-SOLVING SKILL ON JOB SATISFACTION OF PROVINCIAL FOOTBALL REFEREES IN EASTERN ANATOLIAN REGION ${ }^{1}$
}

\author{
Mustafa KIZILKOCA ${ }^{2}$, Ecesu ÖZCAN ${ }^{3} \&$ Veysel ALBAYRAK ${ }^{4}$
}

\begin{abstract}
The aim of this study is to present an effective study on the regional basis that examines the effect of the problem solving skills of the provincial football referees on the level job satisfaction and to contribute to the literature of sports science. The collected data were analyzed with SPSS 25.0 package program and frequency analysis, factor analysis, t test, ANOVA and regression analysis were applied to the data set which parametric tests were used to analyze. From the findings of the analysis, it was concluded that problem solving skill negatively affects job satisfaction, and in response to other sub-problems, the referees with 5-10 years of professional experience have the highest level of problem solving skills and when compared to men, the average score of problem solving skill and jobs satisfaction of women are higher. Finally, regarding the fact that the problem solving skill is higher in the period of 1-5 years, with respect to years in occupation, it has been thought that the new hired individuals are idealistic due to the competitive factor and economic expectations. The result of the study is that problem solving ability has a negative effect on job satisfaction, which constitutes the problem statement of our

\footnotetext{
${ }^{1}$ Makale yazımı yazar etki oranı: 1.yazar \%40, 2. yazar \%30, 3. Yazar \%30. Bu çalışma özet bildiri

${ }^{2}$ Dr. Öğretim Üyesi, Munzur Üniversitesi, Spor Bilimleri Fakültesi, mkizilkoca@munzur.edu.tr, Orcid: 0000-0003-3636-6971

${ }^{3}$ Araştırma Görevlisi, Munzur Üniversitesi, Spor Bilimleri Fakültesi, ecesuozcan@munzur.edu.tr, Orcid: 0000-0002-2324-365X

${ }^{4}$ Frrat Üniversitesi, albayrakvysl@gmail.com, Orcid: 0000-0003-0131-0978
} olarak III. Uluslararası Beden Eğitimi, Spor, Rekreasyon ve Dans Kongresi'nde sunulmuştur.
\end{abstract}


research. The fact that the demographic distribution is very high in the new generation (22-29 years old) has given us specific results regarding the need for current research with the work discipline, work perspective, emotional state, economic expectations of the individuals of this new generation.

Keywords: Provincial football referees, problem solving-skill, job satisfaction, Eastern Anatolia Region

\section{Doğu Anadolu Bölgesi’ndeki Futbol İl Hakemlerinin Problem Çözme Becerilerinin İş Doyumlarına Etkisinin Araştırılması}

\section{$\ddot{O} z$}

$\mathrm{Bu}$ çalışmanın amacı, il futbol hakemlerinin problem çözme yeteneğinin, iş doyumuna olan etkisini inceleyen etkili, bölgesel düzeyde bir çalışma sunmak ve spor bilimleri literatürüne katkıda bulunmaktır. Toplanan veriler SPSS 25.0 paket programıla analiz edilerek, Parametrik testlerin kullanıldığı veri setine frekans analizi, faktör analizi, t testi, ANOVA ve regresyon analizi uygulanmıştır. Analiz bulgularında problem çözme becerisinin iş doyumunu negatif olarak etkilediği sonucuna ulaşılmış olup, diğer oluşturulan alt problemlere cevap olarak, göre ise 5-10 yıl arası meslek deneyimine sahip hakemlerin problem çözme becerisinin en yüksek seviyede olduğu ve kadınların erkeklere oranla problem çözme becerileri ve iş doyumu düzeyleri ortalama puanlarının daha yüksek olduğu bulgusuna ulaşılmıştır. Son olarak problem çözme becerisinin meslek yılına göre 1-5 yıl arası sürede yüksek çıkması ile ilgili olarak, yeni işe giren bireylerin rekabet unsuru ve ekonomik beklentilerden kaynaklı olarak idealist olduğu düşünülmektedir. Araştırmamızın problem cümlesini oluşturan, problem çözme becerisinin iş doyumuna negatif yönlü etki ettiği sonucu bizlere; demografik dağılımın yeni nesilde (22-29 yaş) çok olması, bu yeni jenerasyondan oluşan bireylerin iş disiplini, işe bakış tarzı, duygu durumu, ekonomik beklentileri ile güncel araştırmalara ihtiyaç olduğu ile ilgili özgün sonuçlar vermiştir.

Anahtar Kelimeler: Futbol il hakemi, problem çözme becerisi, iş doyumu, Doğu Anadolu Bölgesi

\section{INTRODUCTION}

Problem-solving skill has an important effect on proceeding our daily lives stably. Problem-solving skill, which is defined to be able to cope with the problems individuals face, is a very important survival skill that influences everything one does in all stages of life. This skill has an important effect on coping process of one's with oneself and others (Barut and Y1lmaz, 2000; as cited in Ülger, 2003).One's high level of problem-solving skill can make us think that that person's social adaptation level is also high. As making strong spontaneous 
decisions is important at work, people in charge are required to diagnose the problems correctly and to have problem-solving skill more than to be multidiciplinary, a good communicator, determined, self-confident, good at socialrelations, an efficient decision-maker, and to have a sense of responsibility, efficient knowledge and experience, the ability of efficient decision making (Ülger, 2003; as cited in Çelikten, 2001). Most of the administrators, school administrators especially in developed countries, are not aware of solving a problem through the scientific methods although they believe that they have to solve it. It has been determined that they try to find the rightanswers instead of asking right questions and try to find a solution through predictions instead of analyzing the problem and its causes (Çelikten, 2001; as cited in Yerli, 2009). According to Samanc1 (2018), the first step to solve the personal and organizational problems is to understand the problem solving process. We can define problem-solving as an intellectual skill that can be learnt and improved by experiences and a well-rounded activity as it contains factors such as intelligence, emotion, willpower and action and it has relation with the one's values, beliefs, abilities and attitudes (Ferhan, 1985; as cited in Şenduran, 2006). It has been thought that having high level problem solving skills not only leads a healthy and safe working environment for the individual and for the people around him, but also changes individuals' job satisfactions to a higher level. A solved problem creates an athmosphere of peace and a systematic job profile. The job satisfaction of the person who spends most of his life at work is important both for individual's health and working environment (Gündüz, 2016). It has been undoubtedly known that job satisfaction is an emotional state and job dissatisfaction has significant negative effects on the environment and the organization, especially on the individual (Derin, 2007; as cited in Nurluöz and Akç11, 2012). Today, organizations /businesses have been creating a working environment that will make the employees happy and make them feel important in the business. In doing so, they both try to make their employees happy, achieve organizational success and increase their organizational commitment (Gündüz, 2016). Apart from the information we have obtained from the positive and negative reflection of job satisfaction, it has been thought that knowing subject. Based on Locke (1969)'s conceptualization, Hulin and Judge (2003) have stated that job satisfaction includes multidimensional psychological responses to one's profession and these responses have cognitive (evaluative), emotional and behavioral components. According to this definition, it has been considered inevitable that the level of our job satisfaction affects our living standards positively or negatively due to the fact that we spend most of our time in business life. In this context, when literature review about problem solving skill and job 
satisfaction is done, joint studies have been reached. In a research conducted on managerial people from the collaborations reached, it has been concluded that when individuals' satisfactions in their work increase, they feel more confident and they show more moderate attitudes towards the solutions of the problems they face in the organization, and they can control thier emotions and behaviours, which are important throughout solution processes and thus they could display more skills in problem solving skill (Ayres and Malouff, 2007; as cited in Çetin et al., 2011). In the study conducted by Koçak and Eves (2010), it has been revealed that the problem solving skills of school administrators will increase as their job satisfaction levels increase, or their job satisfaction levels will decrease as their problem solving skills decrease. Therefore, based on the results obtained from the studies, it has been thought that the lower level of problems in the working environment provincial referees who work actively have and the higher problem solving capacity individuals have, the less stressful they will be and the higher job satisfaction they will have accordingly. In the light of this basic objective, the responses to the following questions were sought:

Does the problem solving skill of provincial referees actively working in the eastern Anatolia Region have a impact on job satisfaction?

Do the problem solving skills and job satisfaction levels of provincial referees actively working in the Eastern Anatolia Region differ according to gender?

Do the problem solving skills and the job satisfaction levels of provincial refeeres actively working in the Eastern Anatolia region differ according to age?

Do the problem solving skills and the job satisfaction levels of the provincial refeeres actively working in the Eastern Anatolia Region differ according to education?

Do the the problem solving skills and job satisfaction levels of provincial referees actively working in the Eastern Anatolia Region differ according to years in occupation?

\section{METHODOLOGY}

This research, which aims to examine the problem solving and job satisfaction levels of provincial football referees who are active football referees, is a descriptive research in thescanning model. Scanning models are research approaches that aim to describe a situation that existed in the past or still exists as it exists. The event, individual or object that is the subject of the research is tried to be defined in its own conditions and as it is (Karasar, 2005). 
An Investıgatıon of Effect of Problem-Solving Skill on Job Satisfaction of Provincial Football Referees in Eastern Anatolian Region

\section{Universe and Sample}

Research universe consists of active football referees registered as provincial referees in Turkey Football Federation and working in Eastern Anatolia region. In this context, it has beeen recorded that in 2018-2019 the number of registered provincial referees from 14 provinces in Eastern Anatolian Region (Ağrı, Ardahan, Bingöl, Bitlis, Elazı̆̆, Erzincan, Erzurum, Hakkari, Iğdır, Kars, Muş, Tunceli, Van) is 332. 163 active provincial football referees participated in the research. It has been stated that, in a study with a universe of 3200 , the number of samples is 357 at $95 \%$ confidence level (Cohen et al., 2007). Therefore, it can be said that the sample obtained in this research represents the universe.

\section{Data Collection}

Problem Solving Inventory: Problem solving skills inventory, developed by Heppner and Peterson (1982) and the Turkish adaptation was measured by Taylan (1990) has been used to determine the problem-solving skills level of provincial football referees and it is sufficient to measure the individual's own perception of problem solving skills. Inventory is a Likert-type scale scored between 1 and 6.The Cronbach Alpha internal consistency coefficient obtained for the whole scale by the researchers who developed the inventory has been found to be 0.90 .

Job Satisfaction Scale: this scale is the Minnesota Job Satisfaction Scale consisting of 20 questions was developed by Weiss et al. (1977) to measure the level of job satisfaction. It was translated into Turkish and the validity and reliability studies were conducted by Baycan (1985) (Cronbach alfa=0.77). Minnesota Job Satisfaction Scale is a 5-point Likert-type scale and there is no reverse question on the scale. Minnesota Job Satisfaction Scale consists of 20 questions with characteristics that determine the level of internal, external and general satisfaction: questions $1,2,3,4,7,8,9,10,11,15,16,20$ measure perception of internal satisfaction; questions 5,6,12,13,14,17,18, 19 measure perception of external satisfaction and the addition of internal and external satisfaction equal to total satisfaction.

\section{Data Analysis}

In this study in which provincial football referees working in Eastern Anatolian Region have participate, the data has been collected through the questionnaire technique. The gathered data has been analyzed by using SPSS 25.0 
program. Frequency analysis, factor analysis, t-test, ANOVA and regression analysis have been applied to the set of data which parametric tests have been used to analyze.

\section{RESULTS}

\section{An Investigation of Effect of Problem-Solving Skill on Job Satisfaction of Provincial Football Referees in Eastern Anatolian Region}

\section{Table 1}

Factor Analysis for the Dimensions Affecting Problem -Solving Skills and Job Satisfaction

\begin{tabular}{|c|c|}
\hline Factor 1: Problem-Solving Skill (a:0.913) & \\
\hline I believe that I can solve problems that may arise when I encounter a new situation. & .695 \\
\hline If the remedies I use to solve a problem fail, I won't investigate why they fail. * & .596 \\
\hline When I plan to solve a problem, I trust that I can execute that plan. & .596 \\
\hline After making a decision, the result usually fits with what I expect. & .589 \\
\hline I do not produce too many options when considering possible solutions to a problem. * & .587 \\
\hline I trust my ability to solve new and difficult problems. & .576 \\
\hline $\begin{array}{l}\text { When I come across a topic, one of the first things I do is to review the situation and } \\
\text { consider any information that may be relevant to the topic. }\end{array}$ & .571 \\
\hline $\begin{array}{l}\text { While trying to decide on a possible solution to a problem, I do not evaluate the } \\
\text { probability of success of my options individually. } *\end{array}$ & .570 \\
\hline I do not try to combine various ideas when considering ways to deal with a problem. $\Omega$ & .566 \\
\hline $\begin{array}{l}\text { Sometimes instead of taking my time and thinking about my problems, I drift } \\
\text { haphazardly. * }\end{array}$ & .563 \\
\hline $\begin{array}{l}\text { When I become aware of a problem, one of the first things I do is try to figure out exactly } \\
\text { what the problem is. }\end{array}$ & .558 \\
\hline When I have a problem, I try to think of all the ways I can go to solve it. & .558 \\
\hline When I encounter a problem, I am generally sure that I can deal with that situation. & .556 \\
\hline $\begin{array}{l}\text { While trying to make a decision, I measure the results of each option, compare them with } \\
\text { each other, and then decide. }\end{array}$ & .553 \\
\hline $\begin{array}{l}\text { After trying a certain way to solve a problem, I stop and compare the result with the } \\
\text { result I think it should be. }\end{array}$ & .544 \\
\hline $\begin{array}{l}\text { Although I did not notice the solution at the beginning, I have the ability to solve most } \\
\text { of my problems. }\end{array}$ & .540 \\
\hline Before I implement a certain solution plan, I try to predict how it will work. & .529 \\
\hline $\begin{array}{l}\text { When I encounter a problem, I stop before moving on to another topic and think about } \\
\text { that problem. }\end{array}$ & .527 \\
\hline I can often produce creative and effective solutions to solve my problems. & .518 \\
\hline $\begin{array}{l}\text { Sometimes I am so emotionally affected that I do not even consider many of the ways to } \\
\text { deal with my problem. * }\end{array}$ & .516 \\
\hline $\begin{array}{l}\text { One method I often use when trying to solve a problem is to think of similar problems } \\
\text { that have happened to me before. }\end{array}$ & .507 \\
\hline I make decisions then I regret.* & .495 \\
\hline Usually I can make decisions about myself and I like them. & .472 \\
\hline $\begin{array}{l}\text { I do not think in detail about how to gather information to determine exactly what it is } \\
\text { when I encounter a difficult problem. * }\end{array}$ & .460 \\
\hline
\end{tabular}




\section{An Investigation of Effect of Problem-Solving Skill on Job Satisfaction of Provincial Football Referees in Eastern Anatolian Region}

I believe that if I have enough time and effort, it can solve most of the problems I face.

If my initial efforts to solve a problem fail, I doubt that I can deal with that problem. *

When I encounter a problem, I usually do not take into account factors other than me, which may have contributed to this problem. *

I usually act in accordance with the first idea that comes to my mind. *

After solving a problem, I do not think in detail what works and what does not work

when solving this problem. *

When a problem confuses me, I don't try to express my feelings and thoughts in concrete and clear terms.

I examine my emotions to understand how I feel when I encounter a problem.

Sometimes, although I try to solve a problem, I have the feeling that I can not get into

the main subject and deal with unnecessary details. *

When I encounter a problem, I usually follow the first way I can think of to solve it. *

There is a systematic method that I use when comparing the options and making decisions.

Many of the problems I have encountered are more difficult and complex than I can solve.

Factor 2: Job Satisfaction (a: 0.915)

In terms of having a chance to do something using my own skills,

In terms of giving me a chance to use my own methods while doing my job, $\quad .801$

In terms of giving me freedom to implement my own decisions, $\quad .793$

In terms of having a chance to tell people what to do $\quad .769$

In terms of the sense of success I have in return for my work, $\quad .706$

In terms of being put into practice of business decisions, $\quad .683$

In terms of working conditions, $\quad .672$

In terms of having an opportunity to do something for others, $\quad .667$

In terms of having an opportunity to do different things from time to time, 653

In terms of being appreciatedfor a good job I do, $\quad .647$

In terms of management style of my manager's under his/her command, $\quad .621$

In terms of giving me a chance to be a "respected person" in the society, $\quad .616$

In terms ofhaving a chance of being promoted in the business, $\quad .611$

In terms of my colleagues' getting along with each other, $\quad .603$

In terms of my manager's ability to make decisions, $\quad .603$

In terms of providing me with a stable job, $\quad .602$

In terms of being kept busy by my job, $\quad .491$

In terms of havingan opportunity to work alone, $\quad .476$

In terms of having a chance to do things that are not against my conscience 353

In terms of the fee I get for the work I do, $\quad .315$

*Kaiser-Meyer-Olkim Sample Measurement: 0,767 and level of significance: 0,0000

At the beginning of the study, planning was made as 2 factors, as a matter of fact, factor analysis has supported this idea and all scale questions has been distributed as planned in the beginning.A (alpha) values were calculated for the internal consistency of the scale scores. If the answers to the test items are three or more, the Cronbach $\alpha$ coefficient is used. Cronbach $\alpha$ reliability coefficient of .70 and higher seems sufficient for the reliability of test scores (Büyüköztürk, 
2007). The reliability of the scales was verified by finding Cronbach $\alpha$ value as 91.3\% in Factor 1 and 91.5\% in Factor 2.

\section{Table 2}

Comparing Problem Solving and Job Satisfaction Scores of Provincial Football Referees Referees by Gender Variable

\begin{tabular}{lllll}
\hline & Gender & $\mathrm{N}$ & $\mathrm{M}$ & $\mathrm{Sd}$ \\
\hline Problem solving & Female & 22 & 1.805 & .6674 \\
& Male & 141 & 1.709 & .5956 \\
Job satisfaction & Female & 22 & 4.070 & .7443 \\
& Male & 141 & 3.849 & .6655 \\
\hline
\end{tabular}

$N=$ number,$\quad M=$ average, $S D=$ standart deviation

In Table 2, as a result of the examination of their average values, it has been observed that both the problem solving skills and job satisfaction levels of the female provincial football referees are higher than the male provincial football referees.

\section{Difference by Gender Variable}

\section{Table 3}

$\mathrm{t}$ Test in Terms of Job Satisfaction and Problem Solving Skill by Gender

\begin{tabular}{llll}
\hline & $\mathrm{t}$ & $\mathrm{df}$ & Sig. \\
\hline Problem-solving skill & .692 & 161 & .490 \\
Job satisfaction & 1.424 & 161 & .156 \\
\hline
\end{tabular}

$t=t$ value, $d f=$ degrees of freedom, sig $=$ significance grade

"Do the problem solving skills of provincial football referees actively working in the Eastern Anatolia Region differ according to gender?" As an answer to the question, in Table 3 it is seen that the problem solving skills of provincial football referees do not differ in terms of gender variable ( $p>.05)$.

"Do the job satisfaction levels of provincial football referees actively working in the Eastern Anatolia Region differ according to gender? "As an answer to the question, in Table 3 it is seen that the job satisfaction levels of provincial football referees do not differ in terms of gender variable ( $p>.05)$. 
An Investigation of Effect of Problem-Solving Skill on Job Satisfaction of Provincial Football Referees in Eastern Anatolian Region

\section{Difference by Age Variable}

\section{Table 4}

Anova Test Resultof Problen Solving Skills and Job Satisfaction

\begin{tabular}{lll}
\hline Factor & F & Sig. \\
\hline Problem Solving Skill & 2.007 & .081 \\
Job Satisfaction & .520 & .761 \\
\hline
\end{tabular}

$F=$ frequency, sig = significance grade

"Do the problem solving skills of provincial refeeres actively working in the Eastern Anatolia region differ according to age?" As an answer to the question, in Table 4 it is seen that there is no significant difference in the problem solving skills of provincial football referees regarding their age ( $p>.05)$.

"Do the job satisfaction levels of provincial refeeres actively working in the Eastern Anatolia Region differ according to age? " As an answer to the queston, in Table 4 it is seen that there is no significant difference in the job satisfaction levels of provincial football referees regarding their age. $(p>.05)$.

\section{Difference by Years in Occupation Variable}

\section{Table 5}

Anova Test Result of Problen Solving Skills and Job Satisfaction Factor

\begin{tabular}{lll} 
& F & Sig. \\
\hline Problem Solving Skill & 3.393 & .019 \\
\hline Job Satisfaction & .171 & .916 \\
\hline
\end{tabular}

$F=$ frequency, sig $=$ significance grade

"Do the problem solving skills levels of provincial football referees actively working in the Eastern Anatolia Region differ according to years in occupation?" As an answer to the question, in Table 5 it is seen that there is a statistically significant difference in the problem solving skills of provincial football referees regarding years in occupation variable $(p<.05)$.

"Do the job satisfaction levels of provincial referees actively working in the Esstern Anatolia Region differ according to years in occupation? "As an answer to the question, in Table 5it is seen that there is no significant difference 
in the job satisfaction levels of provincial football referees regarding years in occupation variable $(\mathrm{p}>.05)$.

\section{Difference by Education Variable}

\section{Table 6}

Anova Test Result of Problen Solving Skills and Job Satisfaction Factor

\begin{tabular}{llc}
\hline & F & Sig. \\
\hline Problem Solving Skill & 690 & .503 \\
Job Satisfaction & .036 & .965 \\
\hline
\end{tabular}

F=frequency, sig= significance grade

"Do the problem solving skills of the provincial refeeres actively working in the Eastern Anatolia Region differ according to education?' As an answer to the question, in Table 6 it is seen that there is no significant difference in the problem solving skills of football city referees regarding their education variables $(\mathrm{p}>.05)$.

In table 6, "Do the job satisfaction levels of provincial referees actively working in the Eastern Anatolia Region differ according to education?'As an answer to the question, in Table 6 it is seen that there is no significant difference in the job satisfaction levels of provincial football referees regarding their education variables $(\mathrm{p}>.05)$.

To find an answer to the key question of this study "Does the Problem Solving Skill of Provincial Referees Actively Working in the Eastern Anatolia Region Have an Impact on Job Satisfaction?", univariate regression analysis was conducted. According to the result of Regression analysis, the 1-unit change in the problem-solving skill variable causes a decrease in the job satisfaction variable by $-0,216$. That is, problem solving ability negatively affects job satisfaction. Multiple linear connections were examined in order to provide more reliable results for regression analysis. Accordingly, VIF values are requested to be less than 10 (Albayrak, 2008).

\section{DISCUSSION}

In the study, when comparing the problem solving and job satisfaction scores of the provincial football referees regarding gender variable, it has been found that the average scores of the problem solving skills of the female provincial football referees were higher than the male provincial football referees. In the study of Bezci (2010) it was concluded that the average values of female 
An Investigation of Effect of Problem-Solving Skill on Job Satisfaction of Provincial Football Referees in Eastern Anatolian Region

taekwondo coaches' problem solving skills were higher than male taekwondo coaches, which supports this study. In the study of Ötkan (2018) and Paydaş (2019) it was found that the average score of problem solving skills of women were higher than men.

When the job satisfaction scores of the provincial football referees are compared considering gender variable, it hasbeen seen that the average job satisfaction of the female provincial football referees is higher than that of the male football city referees. The results obtained in a study where Korman (1992) analyzed the differences in the job satisfaction of men and women and this study are supportive of each other. Şahin (2013) found that female teachers' job satisfaction levels are higher than male teachers'.Özarslan (2010), Akpınar (2010) and Acar (2019) reached the similiar findings that are parallel to the results in this research.

According to the results of provincial football referees for problem solving skill regarding gender variable, it has been seen that the problem solving skills and job satisfaction levels of provincial football referees do not differ in terms of gender variable. Akpınar (2010) found that athletes' problem solving skills subdimensions and total problem solving skills scores did not differ significantly with respect to gender. When the research findings of Yildırım (2016) and Acar (2019) are analyzed, parallel results have been reached.

In the results regarding the job satisfaction levels of the provincial football referees according to the gender variable, a study by Güney et al. (1996) on job satisfaction on 215 staff working in private and public banks found no significant difference between the job satisfaction levels and gender of the employees. Having reached the same result, Türker and Öztürk (2016) concluded that the job satisfaction levels of men and women working in criminal execution institutions operating in the Western Black Sea Division did not differ.

It has been observed that there is no significant difference in the problem solving skills of the provincial football referees in respect with the age variable. Nalbant (2013) concluded that problem solving skill does not differ according to age groups. Kocaman (2006) who worked on coaches and Germi (2006) who worked on managers serving in the Directorate of Youth and Sports reached paralel findings.

It has been observed that there is no significant difference in job satisfaction levels of provincial football referees according to age variable. In 
Özarslan's study (2010), the job satisfaction level of deputy governors did not show a significant difference according to the age variable. In Tekgöz 's (2011) study of the referees regarding their job satisfaction levels, the difference between the average of job satisfaction scores in respect with age variable was not found statistically significant. Türker and Öztürk's (2016) results obtained in a similar study support the findings.

It has been seen that there is no significant difference in problem solving skills of provincial football referees according to the educationalbackground variable. In the research of Nalbant (2013), which was conducted on managers, no significant difference was found according to education variable.

It has been seen that there is no significant difference in job satisfaction levels of provincial football referees according to the educational background variable. Similar to this result, in the study of Tekgöz (2011), no statistically significant difference was found in the average of the job satisfaction scores of the referees according to the educational status variable. In addition, the study results of Nalbant (2013) and Özarslan (2010) support the findings of our research.

It has been observed that there is no significant difference in the job satisfaction levels of provincial football referees according to years in occupation variable. In the study of Yildırım (2016), a statistically significant difference was found in the average scores of the participants' task, professional seniority variable and problem solving skill. In Öncü (2019)'s study, it was seen that teachers' opinions about problem solving skills differed significantly according to their professional seniority. Bezci (2010), in his study of taekvando coaches, concluded that the total problem solving skill scores are at the highest level in the range of 1 to 5 years of service.

It has been observed that there is no significant difference in the job satisfaction levels of provincial football referees according to the variable of years in occupation. The results which were reached in the studies of Şen (2018) and İnandik (2010), were parallel with our findings. The most important result of the researchwas obtained from the regression analysis conducted to measure the effect of problem solving skill on job satisfaction level, and it was concluded that problem solving skill affects job satisfaction negatively. In the literature, a result similar to this result has not been clarified. 
An Investıgatıon of Effect of Problem-Solving Skill on Job Satisfaction of Provincial Football Referees in Eastern Anatolian Region

\section{CONCLUSION}

Regarding one of results of the research, which is that problem solving skill is high in individuals with 1- 5 years in profession, it has been thought that the new hired individuals are idealistic due to the competitive factor and economic expectations. In addition, it has been thought that individuals who have just started this job are more solution-oriented at first, but over time, individuals are less concerned by ignoring the crises and events as they adapt to their colleagues.

Another result of the research, which is that problem solving skill of provincial football referees actively working in Eastern Anatolia Region has a negative effect on job satisfaction shows us that we need to reach important conclusions regarding the individuals' work discipline, work style, emotional state and economic expectations regarding the fact that demographic distribution is high in the new generation (aged 22-29 years).

Considering the results of this study, which was carried out on football referees in general, the effect of business blindness and competition on problem solving skills and job satisfaction can be investigated by conducting an expansive and in-depth review. In the next study, the effect of problem solving skill on job satisfaction should be examined according to the economic competence variable. Because women have higher average scores of problem solving and job satisfaction levels, there is a high difference between the average scores regarding gender; this high difference should be explored in detail and improvements related with the problems that men have in business life should be made. Regarding the variable of years in occupation, activities and trainings that provide necessary personnel motivation should be provided to individuals in terms of ensuring the dynamism of the individuals who have been in the business life for many years. Regarding the new generation mindset, by keeping in touch with these individuals through empathy, training conversations about job expectations, economic expectations, life expectations, and business ethics can be provided, and job satisfaction can be guided into a positive direction.

\section{REFERENCES}

Acar, H. (2019). Bocce (volo) Sporcularının Stresle Başa Çıkabilme Becerileri ile Problem Çözme Becerileri Arasındaki İlişkinin İncelenmesi. Yayınlanmış yüksek lisans tezi, Bartın Üniversitesi Sosyal Bilimler Enstitüsü. 
Akpınar, S. (2010). Spor Federasyonlarında Çalışanların, Sosyal Beceri, İş Doyumu ve Problem Çözme Yeterlilikleri Üzerine bir Araştırma. Yayınlanmış yüksek lisans tezi, Sağlık Bilimleri Enstitüsü Gazi Üniversitesi.

Albayrak, A. S. (2008). Değiş̧en varyans durumunda en küçük kareler tekniğinin alternatifi ağırlıklı regresyon analizi ve bir uygulama. Afyon Kocatepe Üniversitesi I.I.I.B.F. Dergisi, 10(2).

Ayres, J. \& Malouff, J. M. (2007). Problem-solving training to help workers increase positive affect, job satisfaction, and life satisfaction. European Journal of Work and Organizational Psychology, 16(3), 279-294. https://doi.org/10.1080/13594320701391804

Barut, Y. \& Yılmaz, M. (2000). Beden eğitimi ve spor bölümüne ve eğitim fakültesine devam eden öğrencilerin problem çözme becerilerinin çeşitli değişkenler açısından incelenmesi. Uluslararası I. Spor Bilimleri Kongresi Bildirileri, 290-297.

Baycan, A. (1985). An Analysis of Several Aspects of Job Satisfaction Between Different Occupational Groups. Boğaziçi Üniversitesi yayınlanmamış yüksek lisans Tezi.

Bezci, Ş. (2010). Taekwondo Antrenörlerinin Stresle Başa Çıkma ve Problem Çözme Becerileri Arasındaki İlişkinin İncelenmesi. Yayınlanmış doktora tezi, Gazi Üniversitesi Eğitim Bilimleri Enstitüsü.

Büyüköztürk, Ş. (2007). Sosyal Bilimler için Veri Analizi El Kitabı. Pegem A Yayıncilik.

Cohen, L., Manion L. \& Morrison, K. (2007). Research Methods in Education. (6th edition), Routledge.

Çelikten, M. (2001). Okul yöneticilerinin problem çözme becerisi. Kuram ve Uygulamada Egitim Yönetimi Dergisi, 7(3), 297-309.

Çetin, F.,Basım, H. \& Karataş, M. (2011). Çalışanların problem çözme becerilerinde örgütsel adalet algısı ve iş tatmininin rolü. Celal Bayar Üniversitesi İktisadi İdari Bilimler Fakültesi Yönetim ve Ekonomi Dergisi, 18(1), 71-85.

Derin, N. (2007). Devlet Hastanelerinde Çalışan Sağlık Personelinin İş Doyum Düzeyleri ve Etkileyen Faktörler. Yayınlanmış yüksek lisans tezi, Eskişehir Osmangazi Üniversitesi Sağlık Bilimleri Enstitüsü. 
An Investigation of Effect of Problem-Solving Skill on Job Satisfaction of Provincial Football Referees in Eastern Anatolian Region

Ferhan O. (1985). Orta Dereceli Okullarda Öğretim, Amaç, İlke, Yöntem ve Teknikler. Emel Matbaacilik.

Germi, H. (2006). Gençlik ve Spor Genel Müdürlüğünde Görev Yapan Spor Yöneticilerinin Problem Çözme Becerilerinin Değerlendirilmesi. Yayınlanmış yüksek lisans tezi, Ankara Üniversitesi Sağlık Bilimleri Enstitüsü.

Gündüz, G.O. (2016). Banka Çalışanlarında İş Doyumu ve İş Doyumunun Örgütsel Bă̆lllı̆̆a Etkisi. Yayınlanmamış yüksek lisans tezi, Gazi Üniversitesi Eğitim Bilimleri Enstitüsü.

Güney, A. Erdem, Ü., Zafer, B. \& Hepcan, Ș. (1996). Peyzaj Konstrüksiyonu Donatı Elemanları. E. Ü. Zir. Fak. Yayınları No: 514.

Heppner, P.P. \& Petersen, C.H. (1982). The development and implications of a personal problem solving inventory. Journal of Counseling Psychology, 29(1), 66-75.

Hulin, C. L. \& Judge, T. A. (2003). Job attitudes. In W. C. Borman, D. R. Ilgen, \& R. J. Klimoski (Eds.). Handbook of Psychology: Industrial and Organizational Psychology. John Wiley \& Sons Inc.

İnandık, Z. (2010). Müzik Öğretmenlerinin İş Doyumu Düzeylerinin Farklı Demografik Özelliklere Göre İncelenmesi. Yayınlanmış yüksek lisans tezi, Gazi Üniversitesi Eğitim Bilimleri Enstitüsü.

Karasar N. (2005). Scientific Research Approach. Nobel publishing distribution.

Kocaman, H. (2019). Yüzme Antrenörlerinin Problem Çözme Becerileri ve Karar Verme Stratejilerinin Incelenmesi. Yayınlanmış yüksek lisans tezi, Gazi Üniversitesi Sağlık Bilimleri Enstitüsü.

Koçak, R. \& Eves, S. (2010).Okul yöneticilerinin iş doyumları ile problem çözme becerileri arasındaki ilişki. Uluslararası İnsan Bilimleri Dergisi, 7(1),193212.

Korman, J. (1992). A social learning theory of career selection. Journal of Career Counseling, 7, 6-10.

Locke, E. A. (1969). What is job satisfaction? Organizational Behavior and Human Performance, 4, 309-336. 
Nalbant, İ. (2013). Yöneticilerin Problem Çözme Becerilerinde İ̧ Doyumunun ve Algllanan Örgütsel Desteğin Rolü. Yayınlanmamış yüksek lisans tezi, Harp Akademileri Komutanlığı Stratejik Araştırmalar Enstitüsü.

Nurluöz, Ö. \& Akçıl, U. (2012). Hemşirelerin iş güçlüğünü oluşturan değişkenlerinin iş doyumu ile karşılaştırmalı analizi. Hacettepe Üniversitesi Egitim Faküitesi Dergisi, 2, 77-86.

Öncü, H. (2019). Okul Öncesi Öğretmenlerinin Problem Çözme Becerileri ile Öğrenen Özerkliğini Destekleme Davranışları Arasındaki İlişki. Yayınlanmamış yüksek lisans tezi, Sütçü İmam Üniversitesi Sosyal Bilimler Enstitüsü.

Ötkan, C.Ç. (2018). Basketbol Antrenörlerinin Problem Çözme Becerilerinin ve Karar Verme Yöntemlerinin İncelenmesi. Yayınlanmamış yüksek lisans tezi, Gazi Üniversitesi Sağlık Bilimleri Enstitüsü.

Özarslan, M. (2010). Örgütlerde İş Tatmini ve Kişilik Tipi İlişkisi: Vali Yardımcılarına Yönelik Kuramsal ve Uygulamalı bir Araştırma. Yayınlanmamış doktora tezi, Selçuk Üniversitesi Sosyal Bilimler Enstitüsü.

Paydaş, M. (2019). Antrenörlerin Liderlik Tarzlarının Problem Çözme Becerisine Olan Etkisi. Yayınlanmamış yüksek lisans tezi, Karaman Mehmetbey Üniversitesi Sosyal Bilimler Enstitüsü.

Samanc1, B. (2018).Okul Yöneticilerinin Karar Verme ile Problem Çözme Yaklaşımları Arasında İlişkisel ve Karşılaştırılmalı Çözümlemeler: Ankara Illi Örnĕ̆i. Yayınlanmamış yüksek lisans tezi, Bahçeşehir Üniversitesi Eğitim Bilimleri Enstitüsü.

Şahin, İ. (2013). Öğretmenlerin iş doyumu düzeyleri. YYÜ Ĕgitim Fakültesi Dergisi, X(1), 142-167.

Şen, İ. (2018). Üniversite Çalışanlarının İş Tatmini ve Örgütsel Băğlı̆̆g Olan Etkisine Dönük bir Alan Araştırması: Karabük Üniversitesi Idari Personel Örneği. Yayınlanmamış yüksek lisans tezi, İstanbul Üniversitesi Sosyal Bilimler Enstitüsü.

Şenduran, F. (2006). Askeri Liselerde Sporcu Öğrenciler ile sporcu Olmayan Öğrencilerin Problem Çözebilme, Strese Karşı Koyabilme, Uyum 
An Investigation of Effect of Problem-Solving Skill on Job Satisfaction of Provincial Football Referees in Eastern Anatolian Region

Becerileri ve Başarı Düzeyleri. Yayınlanmamış doktora tezi, Marmara Üniversitesi Sağlık Bilimleri Enstitüsü.

Taylan, S.(1990). Heppner'in Problem Çözme Envanterinin Uyarlama Güvenirlik ve Geçerlik Çalışmaları. Yüksek Lisans tezi, Ankara Üniversitesi Sosyal Bilimler Enstitüsü.

Tekgöz, Ü. (2011). Futbol Hakemlerinin İş Stresi, İş Tatmini ve Yaşam Tatmin Düzeyleri Arasındaki İlișkilerin İncelenmesi: 3. Bölge Hakemleri Üzerinde bir Araştırma. Yayınlanmamış yüksek lisans tezi, Erciyes Üniversitesi Sosyal Bilimler Enstitüsü.

Türker, N. \& Öztürk, İ. (2016). İnfaz koruma memurlarının iș doyumu ve örgütsel bağl111kları: batı karadeniz bölümü örneği. Karabük Üniversitesi Sosyal Bilimler Enstitüsü Dergisi, 2, 56-78.

Ülger, Ö. E. (2003).Okul Yöneticilerinin Problem Çözme Becerilerinin Liderlik Davranışlarıyla İlişkisi. Yayınlanmamış yüksek lisans tezi, Beykent Üniversitesi Sosyal Bilimler Enstitüsü.

Weiss, D.J., Dawis, R.V. England, G. W. \& Lofquist, L. H. (1967). Manual for the Minnesota Satisfaction Questionnaire. Minnesota Studies in Vocational Rehabilitation University of Minnesota, 22.

Yerli, S. (2009).̇llk ve Orta Öğretim Okullarındaki Yöneticilerin Duygusal Zekâ ve Problem Çözme Becerileri Arasındaki İlişki. Yayınlanmamış yüksek lisans tezi, Maltepe Üniversitesi, Sosyal Bilimler Enstitüsü.

Yıldırım, M. (2016). Doğu Anadolu Bölgesi'nde Gençlik ve Spor Il Müdürlükleri'nde Çalışan Personelin Problem Çözme Becerisinin Değerlendirilmesi. Yayınlanmamış yüksek lisans tezi, Fırat Üniversitesi Sağlik Bilimleri Enstitüsü. 